\title{
Strategies and arguments of ergonomic design for sustainability
}

\author{
Antonio Marano a, ${ }^{\text {, }}$, Giuseppe Di Bucchianico ${ }^{\mathrm{a}}$ and Emilio Rossi ${ }^{\mathrm{a}}$ \\ ${ }^{a}$ Ergonomics and Design for Sustainability Research Unit, IDEA Department, University of Chieti-Pescara, Viale \\ Pindaro, 42, 65127 Pescara, Italy
}

\begin{abstract}
Referring to the discussion recently promoted by the Sub-Technical Committee $n^{\circ} 4$ "Ergonomics and design for sustainability", in this paper will be shown the early results of a theoretical and methodological study on Ergonomic design for sustainability. In particular, the research is based on the comparison between the common thematic structure characterizing Ergonomics, with the principles of Sustainable Development and with criteria adopted from other disciplines already oriented toward Sustainability. The paper identifies an early logical-interpretative model and describes possible and relevant Strategies of Ergonomic design for sustainability, which are connected in a series of specific Sustainable Arguments.
\end{abstract}

Keywords: Principles of sustainable development, Ergonomic design for sustainability, Design for sustainability, Strategies of ergonomic design for sustainability

\section{Introduction}

In the framework of Design, sustainable development requires new forms of well-being less tied to the acquisition and use of artifacts, and more able to recognize and exploit the quality of the physical and social environment in which we live in by means of sustainable solutions such as system of products, services, knowledges which can facilitate users in their target achievement. Under its disciplinary guidance, Ergonomics has already pursued the "human well-being" through the design of tangible and intangible "comfortable" goods such as objects, tools, tasks, operative procedures, services, environments and organizational systems of living and working. Using specific methodologies and advanced research tools, Ergonomics gets a contribute to product innovation in design fields (industrial design, architecture, urban planning, organizational structures and processes in general), through the study of the risk factors, security, adaptability, usability and pleasantness of use. Being Ergonomics oriented towards well-being, it is also prepared to foresee and extend its reasoning even to sustainable parameters. What is lacking, however, is the start of a process of evolution in its currently available theoreti- cal and procedural apparatus, in order to research for design solutions, which would be "comfortable" (basic performance qualities that should belong to all artifacts and not only to those so-called as "ergonomic"), but, moreover, in tune with the new idea of sustainable well-being growing in the scientific communities of several disciplines like design ones, social ones and economic ones.

\section{Objectives}

Referring to this problematic scenario and according to the discussion promoted by the Sub-Technical Committee $\mathrm{n}^{\circ} 4$ "Ergonomics and Design for Sustainability" [3], as one of the four Sub-Technical Committee that works within the Technical Committee "Human Factors and Sustainable Development", this paper shows the early results of a theoretical and methodological study about Ergonomic design for sustainability.

The main goal of the study was the individuation and the setting-out of a research methodology for the definition of Ergonomic design for sustainability criteria. The specific research objectives were: the

\footnotetext{
*Corresponding author. E-mail: a.marano@unich.it.
} 
individuation of a logical-interpretative filter for the comparative analysis between sustainable development principles and criteria, suggestions and guidelines adopted by a sample group of disciplines already oriented to sustainability; application of this logicalinterpretative model for the construction of an early Thematic Table concerning Ergonomics for Sustainability; individuation of some Strategies and relative Arguments of Ergonomic design for sustainability.

\section{Method}

The research was conducted following a logical path divided in four different phases here described and shown in the following methodological scheme (see Figure 1):

\subsection{Definition of a theoretical framework of sustainability}

The start of research concerned the definition of a conceptual framework of knowledge about sustainability issues. Basic notions of sustainable development have identified, its objectives and its different dimensions of development on the economic level, on the social one and on the environmental one [6-8]. In particular, four principles on which the sustainability is based have been analyzed [4]: the recognized value of ethic, the respect for environment and for ecosystem, the promotion of knowledge and, finally, the incentive to participation. The interpretative analysis of these Sustainable Principles has permitted, moreover, to point out some strategic Keywords composed by terms and expressions used to define New Themes (NT) characterizing Ergonomics for Sustainability.

\subsection{Individuation of multidisciplinary criteria of sustainability and definition of the logical- interpretative model}

The following research phase of guidance has analyzed a sample group of disciplines already oriented toward sustainability; precisely, Design for Sustainability [5] and Sustainable Architecture [1] for planning fields, Sustainable Economics [2-7] and Sustainable Psychology for socio-ethical fields. In this way it has been possible to trace a common logical process of interpretation and elaboration that has allowed, to different disciplinary fields, to define, according to different principles of sustainable development, criteria and indexes, guidelines and standards for Sustainability. From the critical review of results is derived a logical-interpretative model adopted later in the following construction phase of the Ergonomics for Sustainability Thematic Table.

Figure 1

Methodological path of the research

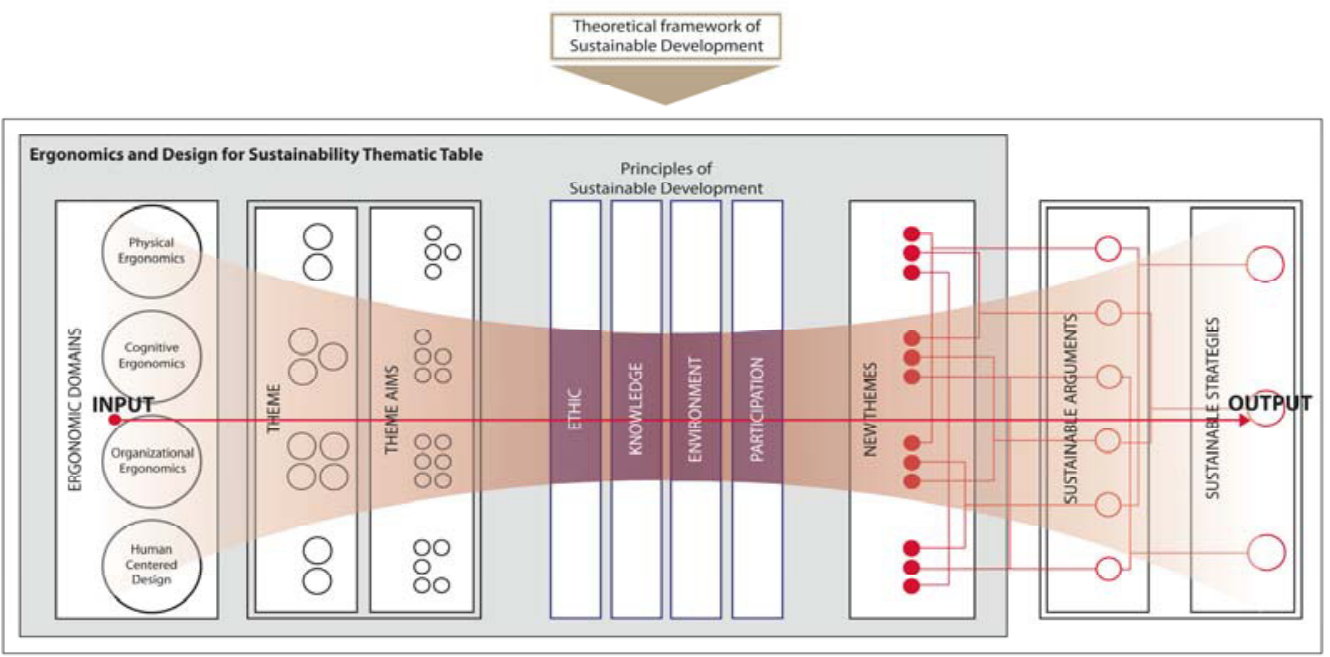

Multidisciplinary Criteria of Sustainability 


\subsection{Construction of the Ergonomics for Sustainability Thematic Table}

The Ergonomics for Sustainability Thematic Table (see Table 1) is divided in four Domains of Specialization (DS) consisting of Physical Ergonomics, Cognitive Ergonomics, Organizational Ergonomics and Human-Centered Design (first column of the Table 1), themselves articulated in Themes $(\mathrm{T})$ (second column of the Table 1) and their relative Theme Aims (TA) (third column of the Table 1). Overall, this group of elements shows the common thematic structure that is reported into the Ergonomic Discipline (ED) literature. The qualitative evaluation between Themes and the four Sustainable Principles (SP), SP1 - the ethic value, SP2 - the knowledge factor, SP3 - the environmental respect, SP4 - the participation, (fourth column of the Table 1 and its sub-columns), obtained through their expressions and their keywords, has allowed to generate some New
Themes (NT) of Ergonomics for Sustainabilityas a result of combination and interpolation of:

$$
\mathrm{NT}=\mathrm{TA}+\mathrm{MP}+\mathrm{AP}
$$

where TA is one of the Ergonomic thematic goals, MP is the Main Principle and AP is the Adjunct Principle. Even if it is not always used in association with MP, AP has permitted to extend the meanings of New Themes, seeking a greater adherence to the meaning of Sustainability.

\subsection{Individuation and definition of Strategies and Arguments of Ergonomic Design for Sustainability}

The conclusive elaboration phase of the research concerned, initially, the interpolative aggregation of New Themes (NT) in relevant Arguments of Ergonomic design for sustainability (SA), then, the additional unification of Arguments, identified as follows, in five Strategies of Ergonomic design for sustainability (SS).

Table 1

A semple part of the "Ergonomics for Sustainability" Thematic Table.

\begin{tabular}{|c|c|c|c|c|c|c|c|c|c|}
\hline \multicolumn{3}{|c|}{$\begin{array}{l}\text { Ergonomic Discipline } \\
(E D)\end{array}$} & \multicolumn{4}{|c|}{$\begin{array}{l}\text { Sustainable Principles } \\
(S P)\end{array}$} & \multirow{2}{*}{$\begin{array}{l}\text { Main } \\
\text { Principle } \\
(M P)\end{array}$} & \multirow{2}{*}{$\begin{array}{l}\text { Adjunct } \\
\text { Principle } \\
(A P)\end{array}$} & \multirow{2}{*}{$\begin{array}{l}\text { New Theme } \\
(N T) \\
N T=T A+M P+A P\end{array}$} \\
\hline $\begin{array}{l}\text { Domain of } \\
\text { Specialization } \\
\text { (DS) }\end{array}$ & $\begin{array}{l}\text { Theme } \\
(T)\end{array}$ & $\begin{array}{l}\text { Theme Aim } \\
\text { (TA) }\end{array}$ & 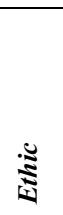 & 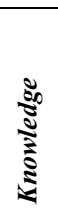 & 武 & 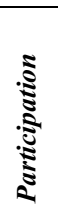 & & & \\
\hline $\begin{array}{l}\text { Physical } \\
\text { Ergonomics }\end{array}$ & $\begin{array}{l}\text { Working } \\
\text { postures }\end{array}$ & $\begin{array}{l}\text { Postural } \\
\text { prevention }\end{array}$ & MP & & & & $\begin{array}{l}\text { Lifestyle } \\
\text { (evolution } \\
\text { and integrity } \\
\text { of) }\end{array}$ & $\begin{array}{l}-- \\
\end{array}$ & $\begin{array}{l}\text { Postural prevention in } \\
\text { new scenarios of work } \\
\text { and domestic activities } \\
\text { correspond to new } \\
\text { sustainable lifestyles }\end{array}$ \\
\hline $\begin{array}{l}\text { Cognitive } \\
\text { Ergonomics }\end{array}$ & $\begin{array}{l}\text { Mental } \\
\text { Workload }\end{array}$ & $\begin{array}{l}\text { Environmental } \\
\text { adaptation }\end{array}$ & MP & & AP & & $\begin{array}{l}\text { Sharing of } \\
\text { ethical values }\end{array}$ & Environment & $\begin{array}{l}\text { Sharing of ethical val- } \\
\text { ues for the valorization } \\
\text { and the regeneration of } \\
\text { human relationships } \\
\text { with living environ- } \\
\text { ments }\end{array}$ \\
\hline $\begin{array}{l}\text { Organizational } \\
\text { Ergonomics }\end{array}$ & $\begin{array}{l}\text { Cooperative } \\
\text { work }\end{array}$ & $\begin{array}{l}\text { Differentiation } \\
\text { of tasks }\end{array}$ & AP & & & MP & $\begin{array}{l}\text { Participation } \\
\text { in design }\end{array}$ & Ecology & $\begin{array}{l}\text { Participation and diffe- } \\
\text { rentiation of individual } \\
\text { and collective tasks in } \\
\text { the ecology of produc- } \\
\text { tive and consumption } \\
\text { system }\end{array}$ \\
\hline $\begin{array}{l}\text { Human } \\
\text { Centered } \\
\text { Design }\end{array}$ & Usability & User pleasure & & MP & & & $\begin{array}{l}\text { Education and } \\
\text { information }\end{array}$ & --- & $\begin{array}{l}\text { Valorization of } \\
\text { personal diversities and } \\
\text { experiences in the } \\
\text { learning } \\
\text { processes }\end{array}$ \\
\hline
\end{tabular}




\section{Results}

From the methodology described until here, some initial specific results have been achieved concern the individuation and the description of possible and significative Strategies of Ergonomic design for sustainability, which correspond the indication of specific sustainable topics. In particular, the Sustainable Strategies concern:

\section{Sustainable Strategy “A”: The optimization of the ergonomic life of products, services and workplaces}

It arises from the consideration that, Ergonomic Design, when it isn't based on a holistic approach, tends to create artifacts for a rapid and inevitable "ergonomic obsolescence", that it determines due to the change of any physical, social or cultural bond. In the Ergonomic design for sustainability this Strategy raises the following question: how to make "comfortable" objects, services, existing living spaces and workplaces preserving, at the same time, also the ergonomic "durability"? In this problematic scenario some Arguments of Ergonomic design for sustainability are identified according to the described methodological process. In the first exemplification they are:

- the postural planning for ergonomic "durability";

- the workplaces and the workspaces from UserCentered Design (UCD) to Social-Centered Design (SCD);

- the ergonomic quality of products and equipment in the evolution of users' physical and socio-cultural factors.

Sustainable Strategy "B”: The facilitation of sharing and socializing modalities of products, services, work activities and management

It arises from the consideration that the contribution of Ergonomics to project is often addressed to the research of solutions that improve system of artifacts which users usually use, rather to investigate possible alternatives to proliferation of products and, consequently, on increasing consumption of resources. In the Ergonomic design for sustainability approach this Strategy raises the following question: how to develop an ergonomic approach that is able to pursue the well-being of people toward the sharing and the socializing, reducing in this way the use of personal and collective tools or "prosthesis"? In this problematic scenario some Arguments of Ergonomic design for sustainability are identified according to the described methodological process. In the first exemplification they are:

- the management of human resources in the new socio-ethical work prospective;

- the assessments of the "shareability" and "socializing" abilities of products and services;

- the redefinition of "work group" in the new working and self-productive activities;

- the "shared planning" in the "shared use" of products and services.

Sustainable Strategy " $C$ ”: The choice of intelligence systems for learning and developing technical skills and creative capabilities

It arises from the consideration that, as you try to reduce human error in the use of systems, less or more complex, it is always present and now it will not be possible to eliminate it completely. An alternative to the so-called "planning in sight of the error" is to consider the error as an "opportunity" of learning through experiences and relations. In the Ergonomic design for sustainability approach this Strategy raises the following questions: how to foster the capacity of technical systems to learn from experience, developing error friendly solutions and increasing the number of it dots inside the net which have own listening capacity and own action abilities? In this problematic scenario some Arguments of Ergonomic design for sustainability are identified according to the described methodological process. In the first exemplification they are:

- the shift from user-friendly systems to errorfriendly ones;

- the evolution of the decisional processes from the development of "how to do" abilities to awareness of "why to do" aims;

- the role of imagination in the development of technical abilities;

- the mental workloads and stress in the creative activities.

\section{Sustainable Strategy “D”: The valorization of contemplative time in the aimed actions}

It arises from the consideration that the aim of systemic efficiency is generally related to the "rapidity" of use, neglecting the "slow" use that, indeed, it could be have other vantages: the "slowness", when is required, promotes the reflection, the learning and the appreciation of the value of things. In the Ergo- 
nomic design for sustainability approach, this Strategy raises the following question: how to generate systems characterized by different temporalities, reducing the average speed of movements and the consumption of resources? In this problematic scenario some Arguments of Ergonomic design for sustainability are identified according to the described methodological process. In the first exemplification they are:

- the planning of work times in the recovery of the value of reflection and care of things;

- the "slow" usability of products and systems;

- the postural assessment in the new forms of creative work;

- the reassessment of the "physical and intelligent" relationship with artifacts and systems.

\section{Sustainable Strategy "E”: The cultural, psychological and economical-productive regeneration of everyday life contexts}

It arises from the consideration that after the new economy crisis that has destroyed the traditional forms of psychological and economical gratification derived to handcrafted know-how, is the moment to imagine new sustainable forms of production and well-being. In the Ergonomic design for sustainability approach this Strategy raises the following question: how to respond to the "creative" instances of "know-how" related to the renewed and innate human desire of pursue the own personal satisfaction from the research of good work made with art, intelligence, manual wisdom and knowledge? In this problematic scenario some Arguments of Ergonomic design for sustainability are identified according to the described methodological process. In the first exemplification they are:

- the work organization and the work management in the sustainable domestic environment;

- the health and the safety in domestic selfproduction activities;

- the architectonic evolution of the productive and sustainable domestic environment;

- the self-learning through products and intentionally "not perfect" systems;

- the art of soft power (the search for minimum power) for the improvement of manual abilities;

- the use, the transmission and the spreading of knowledge and practical experience.

\section{Conclusions}

From a critical reading of the achieved results, it is possible to state that, through the comparative study between the common classic thematic structure of Ergonomics with Principles of sustainable development, and with criteria and suggestions adopted from other disciplinary fields already oriented toward sustainability, it has been possible identify an early logical-interpretative filter for the construction of an Ergonomic design for sustainability Thematic Table. The next sample verification and application of the model has allowed the identification of some Strategies and relative Arguments of Ergonomic design for sustainability. This allows to state that, if the same model of evaluation could be extended to other Domains of Specialization and relative Ergonomic Themes, it could be obtain an early and possible organic framework of the new Ergonomic Design for Sustainability thematic structure.

\section{Credits}

In this paper is shown the result of a common discussion and elaboration work, but the writing of the various paragraphs can be attributed to: Giuseppe Di Bucchianico (Abstract, 1. Introduction and 5. Conclusions), Antonio Marano (2. Objectives and 3. Methods) and Emilio Rossi (4. Results).

\section{References}

[1] G. Bologna, Manuale della sostenibilità. Idee, concetti, nuove discipline capaci di futuro, Edizioni Ambiente, Milan, 2005.

[2] E.H. Daly, Economia ecologica e Sviluppo sostenibile, in: Oikos, 97-115, 1991.

[3] G. Di Bucchianico and A. Marano, Arguments of "Ergonomics and design for sustainability", in: Neue Arbeits - und Lebenswelten gestalten, $56^{\circ}$ Kongress der Gesellschaft für Arbeitswissenschaft, GFA-Press, Dortmund, 2010.

[4] S. Dresner, The Principles of Sustainability, Earthscan publications Ltd, London, 2008.

[5] E. Manzini and F. Jégou, Sustainable everyday: scenarios of urban life, Edizioni Ambiente, Milan, 2003.

[6] G.G. Marten, Human Ecology. Basic concepts for sustainable development, Earthscan publications Ltd, London, 2001.

[7] E. Tiezzi and N. Marchettini, Che cos'è lo sviluppo sostenibile? Le basi scientifiche della sostenibilità e i guasti del pensiero unico. Donzelli editore, Rome, 1999.

[8] World Commission on Environmental Development, Our Common Future. Oxford University Press, Oxford, 1987. 